\title{
Recent Occurrence of PAHs and n-Alkanes in PM2.5 in Seoul, Korea and Characteristics of Their Sources and Toxicity
}

\author{
Minkyung Kang ${ }^{1}$, Kiae Kim ${ }^{1}$, Narae Choi ${ }^{1}$, Yong Pyo Kim ${ }^{2}$ and Ji Yi Lee ${ }^{1, *}$ \\ 1 Environmental Science and Engineering, Ewha Womans University, Seoul 03760, Korea; \\ kcotek@gmail.com (M.K.); rldo428@gmail.com (K.K.); naraechoi1990@gmail.com (N.C.) \\ 2 Chemical Engineering and Materials Science, Ewha Womans University, Seoul 03760, Korea; \\ yong@ewha.ac.kr \\ * Correspondence: yijiyi@ewha.ac.kr; Tel.: +82-2-3277-5945
}

Received: 30 December 2019; Accepted: 18 February 2020; Published: 21 February 2020

\begin{abstract}
Polycyclic Aromatic Hydrocarbons (PAHs) and n-alkanes in particulate matter with an aerodynamic diameter of 2.5 micrometers or less (PM2.5) were quantified at Seoul, Korea in 2018. The seasonal differences in the total concentration of PAHs and n-Alkanes were clear, where winter showed a higher concentration than that of summer. Compared to the PAHs measurements in 2002 at Seoul, the sum of PAHs concentrations in 2018 were reduced from 26.6 to $5.6 \mathrm{ng} \mathrm{m}^{-3}$. Major sources of the observed PAHs and n-alkanes were deduced from various indicators such as diagnostic ratios for PAHs and Cmax, CPI, and WNA (\%) indices for n-alkanes. It was found that in winter coal and biomass combustions, and vehicular exhaust were major sources, while, in summer vehicular exhaust was major source. In addition, in winter, major emission sources were located outside of Seoul. The health effect from the recent level of PAHs was estimated and compared to the previous studies observed in Seoul, and it was found that, recently, the toxicity of PAHs in $\mathrm{PM}_{2.5}$ was significantly decreased, except for in the winter.
\end{abstract}

Keywords: PAHs; n-alkanes; diagnostic ratio; source characteristics; toxicity

\section{Introduction}

Polycyclic Aromatic Hydrocarbons (PAHs) are carbon-structured organic compounds that consist of two or more benzene rings. They are not emitted as a single species, but as a mixture, and their sources are incomplete combustion of fossil fuels such as vehicle emissions, coal combustion, and biomass burning [1,2]. PAHs are significant indicators relating to the adverse health effects of particulate matters (PMs) due to their carcinogenic properties. The United States Environmental Protection Agency (EPA) has listed 16 PAHs as priority pollutants that adversely affect human health; therefore, the control of PAH sources is important to reduce the adverse health effects of PM. The European Union (EU) has also established a health-based standard for PAHs which targets PAHs concentration in ambient air to $1 \mathrm{ng} \mathrm{m}^{-3}$, expressed as concentration of Benzo[a]pyrene (BaP) [3]. China has a standard for Toxic Equivalent Quotient (TEQ) of BaP, whereby it must be controlled to $2.5 \mathrm{ng} \mathrm{m}^{-3}$ daily and an annual average to $1 \mathrm{ng} \mathrm{m}^{-3}$ [4]. However, an established standard for PAHs in South Korea has not been developed.

n-Alkanes are also carbon-structured organic compounds like PAHs, but they are linear carbohydrates which have both anthropogenic and biogenic sources. Fossil fuel combustion and biomass burning are the main contributors to anthropogenic n-alkane sources, and plant wax emission, pollen, and microorganisms largely contribute to biogenic n-alkane sources [5-9]. 
There have been several studies reporting particle-bound PAHs in the ambient air in South Korea [10-14]. These studies reported the level of PAHs in PM and the possibility of long-range transport of PAHs using back trajectory $[15,16]$. In addition, some of the previous studies applied receptor models such as the Chemical Mass Balance (CMB) and Positive Matrix Factorization (PMF) models for the source apportionment $[16,17]$. Coal combustion and biomass burning were identified as a major source of PAHs by the CMB model in the winter of 2002 to 2003 in Seoul, with vehicular emission being the largest PAH contributor for the entire sampling period [16]. The PMF model was applied in Seoul, South Korea, between 2002 and 2013, which found that the contribution of coal combustion decreased, while that of vehicular sources increased during the study period; however, the contribution from biomass burning remained consistent [17].

Numerous studies for PAH characterization in PM have been conducted in various sites worldwide with health risk assessments. Especially, since the emission of fossil fuel combustion in northeast Asian countries such as China and Mongolia has been increasing, recent studies have focused on the health risk assessment of PAHs in PM regarding carcinogenic properties. The identified sources are coal combustion sources and vehicular emissions, and such emission sources are dominant in the colder season [18-21]. In the city center of Ulaanbaatar City, Mongolia, the lifetime inhalation cancer risk for children and adults in the heating season reached $1.00 \times 10^{-5}$, exceeding EPA guidance value by 10 times [19,22]. BaP-TEQ, estimated at several urban areas in China, ranged from 3.31-4.95 $\mathrm{ng} \mathrm{m}^{-3}$, which is higher than China's annual average standard $1 \mathrm{ng} \mathrm{m}^{-3}[3,19]$. However, health risk assessment for PAHs in PM has not been estimated in Seoul, Korea based on recent concentrations of PAHs.

The general approach to classify the sources of PAHs is using a diagnostics ratio. Diagnostics ratio is defined with a pair of PAHs that have similar properties such as molecular weight or formula, but have different physical characteristics such as decay rates. Emission sources can also be identified simply through observing the ratio of individual PAHs. At low temperature, Low Molecular Weight (LMW) PAHs are formed, while at higher temperatures, High Molecular Weight (HMW) PAHs with five or more benzene rings form easily [23]. In addition, combustion of solid fuels such as coal and biomass is a source for LMW and Middle Molecular Weight (MMW) PAHs and liquid fuel combustion such as vehicular emissions is a source for MMW and HMW PAHs [23-26].

To estimate source characteristics of n-alkanes, three indexes are mainly applied to quantify which emission source is dominant. Carbon Preference Index (CPI) is calculated by the ratio of the sum of odd numbered $n$-alkanes to the sum of even numbered n-alkanes. When n-alkanes are emitted solely from anthropogenic sources, the CPI will converge to 1, but the effect of biogenic sources will bring the value closer to 3 or more [27-29]. Second is $C_{\max }$, which is the carbon number of the most abundant species among the extracted n-alkanes. The last index is Wax n-alkanes percentage (WNA, \%), which represents the total percentage of plant wax contribution to the n-alkane concentration [30].

Principle Component Analysis (PCA) is an effective statistical tool to identify independent factor of air pollutants by grouping chemical species which share similarities of variances of the species to give physicochemical significance to these groups. PCA has been widely used to the sources identification of air pollutants in $\mathrm{PM}_{2.5}$ [31,32].

The objective of this study is to (1) evaluate the recent PAH concentrations in Seoul, South Korea with seasonal characteristics of PAHs, and (2) identify the major sources of PAHs in this area based on the PCA with the various diagnostic ratios of PAHs and index of n-Alkanes. Finally, (3) estimate the toxicity of PAHs in $\mathrm{PM}_{2.5}$ in Seoul, Korea in order to provide the basis for the establishment of the ambient air quality standard for PAHs in atmospheric PM in Korea.

\section{Materials and Methods}

\subsection{Sampling}

Samples were collected from the rooftop of Korea Environmental and Technology Institute $\left(37^{\circ} 61^{\prime} \mathrm{N}, 126^{\circ} 93^{\prime} \mathrm{E}\right)$ located in Seoul, South Korea. The sampling site was adjacent to a road in the 
south, a residential area in the north, and Mt. Bukhansan in the northeast. Figure 1 is a map of the sampling site.

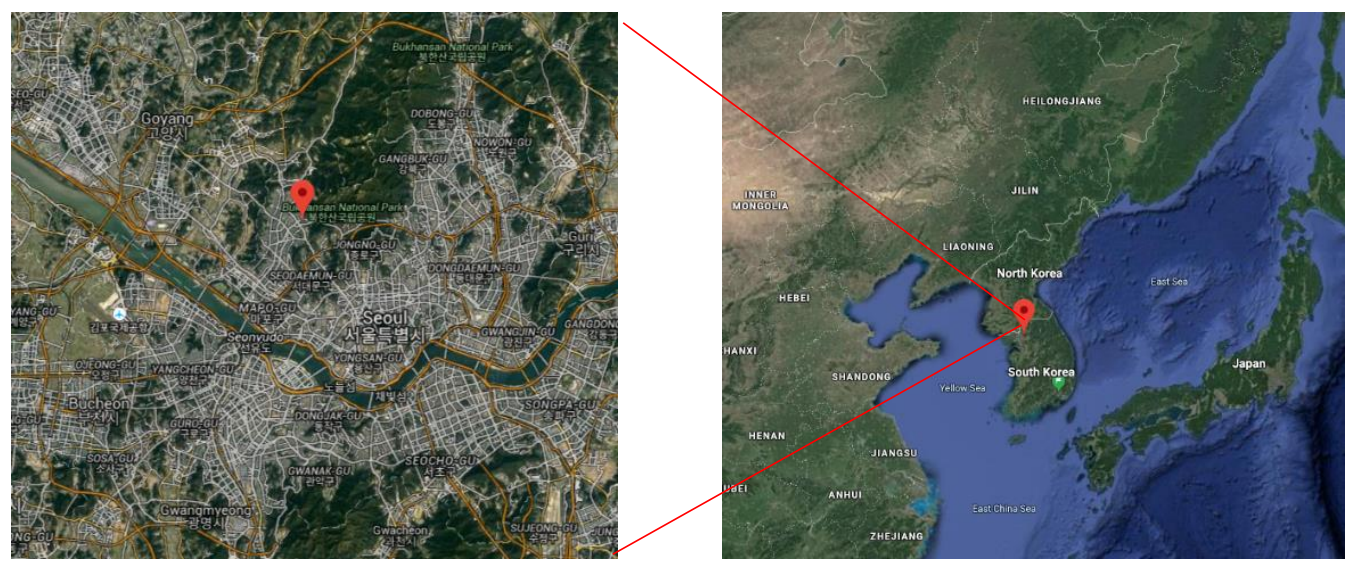

Figure 1. The location of the sampling site is flagged with a red point in the map.

The sampling period was from January 15th 2018 to December 8th 2018, and at least 23 samples were collected for each season. Detailed information on the number of samples and meteorological parames during the sampling period are given in Table 1. Average radiation, temperature and relative humidity (RH) was at maximum in summer. Radiation for winter and fall was similar, however, average temperature for winter $\left(-4.7 \pm 6.1^{\circ} \mathrm{C}\right)$ was below the freezing point. $\mathrm{RH}$ increases from winter to summer. Samples were collected on pre-baked (at $550{ }^{\circ} \mathrm{C}$ for $12 \mathrm{~h}$ ) quartz filters (QFFs, Pall, Tissuequartz-2500QAT-UP, $8 \times 10$ in) with $\mathrm{PM}_{2.5}$ high volume samplers (SIBATA, HV-RW and Tisch $6070 \mathrm{~V}-2.5)$. Samplers were operated at a flow rate of $1000 \mathrm{~L} \mathrm{~min}^{-1}$ for $23 \mathrm{~h}$ for each sample.

Table 1. Number of samples and meteorological parameters during the sampling period for each season.

\begin{tabular}{|c|c|c|c|c|c|}
\hline & Period & $\begin{array}{c}\text { No. of } \\
\text { Samples }\end{array}$ & $\begin{array}{c}\text { Radiation } \\
\left(\mathrm{MJ} \mathrm{m}^{-2}\right)\end{array}$ & $\begin{array}{c}\text { Temperature } \\
\left({ }^{\circ} \mathrm{C}\right)\end{array}$ & RH(\%) \\
\hline Winter & $\begin{array}{c}2018 / 01 / 15 \\
-2018 / 02 / 09\end{array}$ & 25 & $7.8 \pm 3.8$ & $-4.7 \pm 6.1$ & $45.8 \pm 10.5$ \\
\hline Spring & $\begin{array}{c}2018 / 03 / 11 \\
-2018 / 04 / 07\end{array}$ & 28 & $13.8 \pm 3.8$ & $14.4 \pm 4.6$ & $61.4 \pm 11.9$ \\
\hline Summer & $\begin{array}{c}2018 / 08 / 20 \\
-2018 / 09 / 16\end{array}$ & 23 & $14.4 \pm 6.7$ & $24.3 \pm 2.3$ & $67.2 \pm 13.8$ \\
\hline Fall & $\begin{array}{c}2018 / 11 / 05 \\
-2018 / 12 / 08\end{array}$ & 32 & $7.8 \pm 3.4$ & $6.4 \pm 5.0$ & $56.7 \pm 16.7$ \\
\hline
\end{tabular}

\subsection{Analytical Procedure}

A quarter of QFFs were used for each sample extraction. For PAH and n-alkane quantification, internal standardization was applied. The surrogate standards for PAHs were phenanthrene-d10, fluoranthene $\mathrm{d}-10$, chrysene-d12, perylene-d12, and benzo[ghi]perylene-d12, and for n-alkanes, three surrogate standards (C24-d50, C30-d62, and C36-d74) were used. The mixture of the surrogate standards was added to the filters and placed in a $125 \mathrm{~mL}$ amber vial. Particulate PAHs and $\mathrm{n}$-alkanes were then extracted by ultrasonication with DCAM/MeOH (3:1, v/v) solvent twice for $30 \mathrm{~min}$. Then, solvents were evaporated with an evaporator (TurboVaP II, Caliper) at $40^{\circ} \mathrm{C}$ until the total volume of the extracts reached $10 \mathrm{~mL}$. The extracts were filtrated with $0.45 \mu \mathrm{m}$ pore size filters (Acrodisc $25 \mathrm{~mm}$ Syringe Filter, Pall), then concentrated to $500 \mu \mathrm{L}$ at $40{ }^{\circ} \mathrm{C}$ with gentle $\mathrm{N}_{2}$ gas stream using a needle concentrator (\#TS-18821, Reacti-therm). In this study, 14 PAH compounds and 17 n-alkanes were identified using an Agilent 7890B gas chromatograph (GC) with DB-5MS ultra inert column 
$\left(30 \mathrm{~m} \times 0.25 \mathrm{~mm}, 0.25 \mu \mathrm{m}\right.$ thickness, Agilent $\left.{ }^{\circledR} \mathrm{J} \& \mathrm{~W}^{\mathrm{TM}}\right)$ and quantified with a 5977A mass spectrometer (MS) in synchronous selected ion monitoring (SIM)/scan mode. Helium of $99.999 \%$ purity was used as a carrier gas at a flow rate of $1 \mathrm{~mL}$ min- 1 in a GC-MS. A $1 \mu \mathrm{L}$ sample was injected in splitless mode at $240{ }^{\circ} \mathrm{C}$. Mass spectrometry was operated in electron impact (EI) mode at $70 \mathrm{eV}$ at a source temperature of $230^{\circ} \mathrm{C}$.

The quantified compounds and their abbreviations are stated in Table 2. The extraction recovery for PAHs was in the acceptable range from $83 \%$ to $115 \%$, except Cor. The recovery of n-Alkanes was in the acceptable range from $75 \%$ to $129 \%$, except C20. Due to the lowest and highest volatiles of Cor in PAHs and C20 in n-Alkanes, the recovery of Cor and C20 was not stable (Table 2).

Table 2. Quantified Polycyclic Aromatic Hydrocarbons(PAHs), n-Alkanes, and abbreviations and recovery $(\%)$.

\begin{tabular}{ccccc}
\hline PAHs Compounds & Abbrev. & Recovery (\%) & $\begin{array}{c}\text { n-Alkane } \\
\text { Compounds }\end{array}$ & Recovery (\%) \\
\hline Phenanthrene & Phe & $89 \pm 2.0$ & C20 & $59 \pm 18$ \\
Anthracene & Ant & $84 \pm 3.0$ & C21 & $82 \pm 16$ \\
Fluoranthene & Fl & $88 \pm 1.2$ & C22 & $105 \pm 12$ \\
Pyrene & Py & $36 \pm 1.7$ & C23 & $113 \pm 7.0$ \\
Benzo[a]anthracene & BaA & $97 \pm 2.0$ & C24 & $114 \pm 5.0$ \\
Chrysene & Chr & $92 \pm 1.2$ & C25 & $117 \pm 13$ \\
Benzo[b]fluoranthene & BbF & $115 \pm 14$ & C26 & $113 \pm 22$ \\
Benzo[e]pyrene & BeP & $111 \pm 13$ & C27 & $111 \pm 28$ \\
Benzo[a]pyrene & BaP & $100 \pm 9.7$ & C28 & $129 \pm 29$ \\
Perylene & Peryl & $91 \pm 4.5$ & C29 & $118 \pm 11$ \\
Indeno[1,2,3-c,d]pyrene & IcdP & $95 \pm 7.6$ & C30 & $105 \pm 10$ \\
Dibenz[a,h]anthracene & DahA & $97 \pm 7.8$ & C31 & $99 \pm 17$ \\
Benzo[g,h,i]perylene & BghiP & $83 \pm 1.5$ & C32 & $88 \pm 21$ \\
Coronene & Cor & $49 \pm 14$ & C33 & $79 \pm 23$ \\
& & & C34 & $75 \pm 21$ \\
& & & C35 & \\
\hline
\end{tabular}

\section{Results}

\subsection{The Concentrations of PAHs and n-Alkanes in PM2.5}

The annual and seasonal concentrations of total PAHs and n-alkanes are shown in Table 3. Total PAH and n-alkane concentrations for the whole sampling period were $5.6 \pm 7.9 \mathrm{ng} \mathrm{m}^{-3}$ and $17.1 \pm 13.1 \mathrm{ng} \mathrm{m}^{-3}$, respectively. n-Alkane concentration was several folds higher than that of PAHs during the whole period. The winter season recorded the highest average concentration for both compounds (PAHs $16.1 \pm 10.01 \mathrm{ng} \mathrm{m}^{-3} ; \mathrm{n}$-alkanes $28.4 \pm 16.4 \mathrm{ng} \mathrm{m}^{-3}$ ) and the lowest concentration in the summer season for both compounds (PAHs $0.8 \pm 0.5 \mathrm{ng} \mathrm{m}^{-3}$; n-alkanes $6.4 \pm 2.5 \mathrm{ng} \mathrm{m}^{-3}$ ). The average concentration of PAHs for fall $\left(3.8 \pm 2.8 \mathrm{ng} \mathrm{m}^{-3}\right)$ was higher than for spring $\left(1.8 \pm 12 \mathrm{ng} \mathrm{m}^{-3}\right)$, while n-alkanes for spring $\left(16.4 \pm 12.5 \mathrm{ng} \mathrm{m}^{-3}\right)$ and fall $\left(16.3 \pm 7.1 \mathrm{ng} \mathrm{m}^{-3}\right)$ did not significantly differ from each other. 
Table 3. Comparison of PAHs and n-Alkane levels with a previous study in 2002 (unit: $\mathrm{ng} \mathrm{m}^{-3}$ ).

\begin{tabular}{cccc}
\hline & \multicolumn{2}{c}{ This Study } & Previous Study ${ }^{\mathbf{1}}$ \\
& PAHs & n-Alkanes & PAHs \\
\hline Winter & $16.1 \pm 10.01$ & $28.4 \pm 16.4$ & $50.5 \pm 32.3$ \\
Spring & $1.8 \pm 1.2$ & $16.4 \pm 12.5$ & $21.8 \pm 16.1$ \\
Summer & $0.8 \pm 0.5$ & $6.4 \pm 2.5$ & $6.8 \pm 3.9$ \\
Fall & $3.8 \pm 2.8$ & $16.3 \pm 7.1$ & $20.6 \pm 24.0$ \\
Total & $5.6 \pm 7.9$ & $17.1 \pm 13.1$ & $26.6 \pm 28.4$ \\
\hline \multicolumn{4}{c}{${ }^{1}$ Data from 2002 study on PAHs in the ambient air of Seoul [16]. }
\end{tabular}

${ }^{1}$ Data from 2002 study on PAHs in the ambient air of Seoul [16].

Compared with the previous results measured between 2002 and 2003 in Seoul [16], recent annual averaged PAH concentrations in Seoul dropped from $26.6 \mathrm{ng} \mathrm{m}^{-3}$ in 2002 and 2003 to $5.6 \mathrm{ng} \mathrm{m}^{-3}$ in 2018 to be $1 / 5$ in 2018 compared to 2002 and 2003. There are two possible reasons for the decreased $\mathrm{PAH}$ concentrations in Seoul. One is the increase of combustion efficiency of fossil fuel from emission sources of PAHs in Korea. Evidence to prove the combustion efficiency in Seoul is the decrease of Elemental Carbon (EC) concentration in Seoul, as shown in Table 4, which is an indicator of incomplete combustion. Organic Carbon (OC) and EC measurement have been carried out since 2013 at the same sampling site of this study, operated by the Korean National Institute of Environmental Research (NIER) as one of the intensive measurement networks of the NIER. EC concentration has shown a decreasing tendency since 2013, while, OC concentration has not been changed. Compared to the EC concentration in 2013, the EC concentration in 2018 is about half, suggesting higher combustion efficiency of fossil fuel emission sources. In addition, the OC/EC ratios which is one of indicator of secondary formation of OC in PM2.5 has been doubled from 2013 to 2018. It can be explained by an increase in secondary formation or a decreased of primary emission. The consistency of OC concentration with the increasing OC/EC ratios is primarily due to the effect of the decrease of EC concentration. Therefore, the tendency of EC concentration with OC/EC ratio can be one of evidence for the decrease of organic PM in combustion sources. Also, increase of clean fuel usage instead of coal fuel according to the policy of air quality management in Korea is one of possible reason to reduce PAHs concentration at Seoul, Korea. Another possibility is the decrease of PAH concentrations outside of Seoul, including China. Indeed, the recent PAH concentrations in PM measured in China has decreased significantly in recent years [33] (Tables 3 and 4).

Table 4. Average organic carbon (OC) and elemental carbon (EC) concentration with OC/EC ratios in Seoul.

\begin{tabular}{ccccccc}
\hline & \multicolumn{2}{c}{ EC $\left(\mu \mathrm{g} \mathrm{m}^{-3}\right)$} & \multicolumn{2}{c}{ OC $\left(\mu \mathrm{g} \mathrm{m}^{-3}\right)$} & \multicolumn{2}{c}{ OC/EC } \\
\hline Year & Average & SD & Average & SD & Average & SD \\
\hline 2013 & 1.8 & 1.1 & 3.8 & 2.6 & 2.2 & 1.1 \\
2014 & 1.6 & 1.0 & 3.9 & 2.7 & 2.9 & 3.9 \\
2015 & 1.3 & 0.7 & 3.7 & 2.2 & 4.0 & 5.9 \\
2016 & 1.2 & 0.9 & 3.6 & 2.2 & 3.6 & 6.7 \\
2017 & 1.3 & 0.8 & 3.7 & 2.2 & 3.8 & 5.2 \\
2018 & 0.7 & 0.4 & 4.0 & 2.6 & 5.6 & 2.0 \\
\hline
\end{tabular}

\subsection{Seasonal Characteristics of PAHs and n-Alkanes}

Table 5 shows the correlation between PAH and n-alkane concentrations for each season. For the whole period, it shows a strong correlation $(\mathrm{R}>0.73)$. Winter samples show the best correlation $(R=0.80)$, and summer, the weakest correlation $(R=0.30)$, suggesting that in winter, PAHs and $\mathrm{n}$-alkanes have similar emission sources compared to summer (Table 5 ). 
Table 5. PAH and n-Alkane concentration correlation.

\begin{tabular}{cccccc}
\hline & Total Period & Winter & Spring & Summer & Fall \\
\hline Correlation & 0.73 & 0.80 & 0.42 & 0.30 & 0.34 \\
\hline
\end{tabular}

\subsubsection{PAH Seasonal Characteristics}

PAHs are classified by rings, as shown in Figure 2. Only the benzene rings are counted as "rings"; the other cyclic carbon frames are considered " 0.5 rings". Figure 2 is the seasonal averaged ratio of 3-7-ringed PAHs. The composition of PAHs by number of benzene rings shows a seasonal difference. The ratio of PAHs with three benzene rings tends to decrease toward summer, while PAHs with four and six benzene rings show the opposite trend. Since the combustion emission source of LMW-PAHs is coal and biomass combustion and HMW-PAHs Vehicle, the summer is more affected by vehicular emissions and less by solid fuel combustion. Also, this tendency is due to the semi-volatile characteristics of 3 and 4 benzene rings of PAHs in the ambient air. (Figure 2).

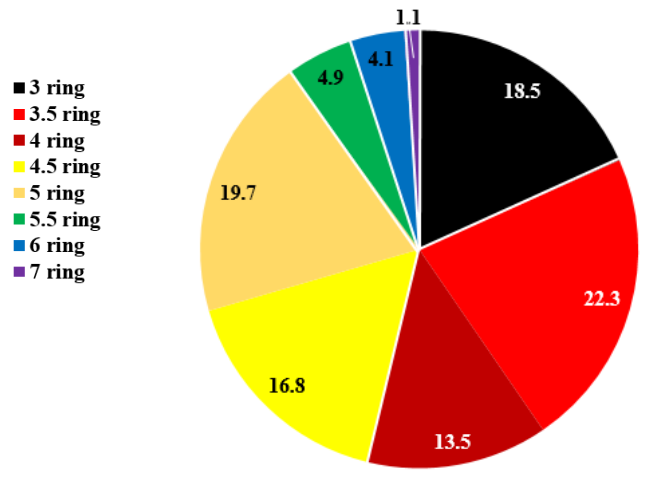

(a)

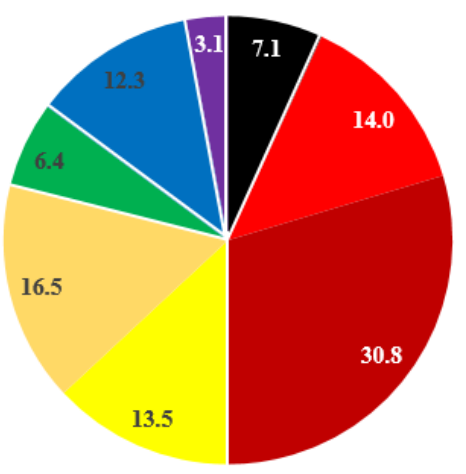

(c)

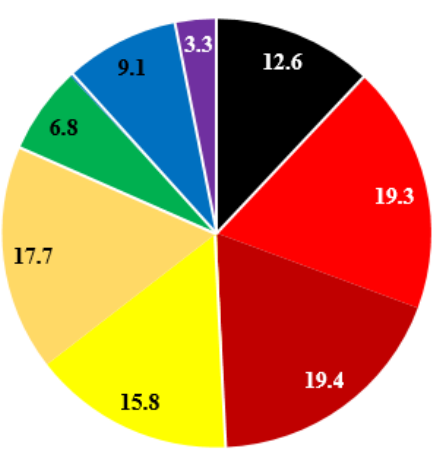

(b)

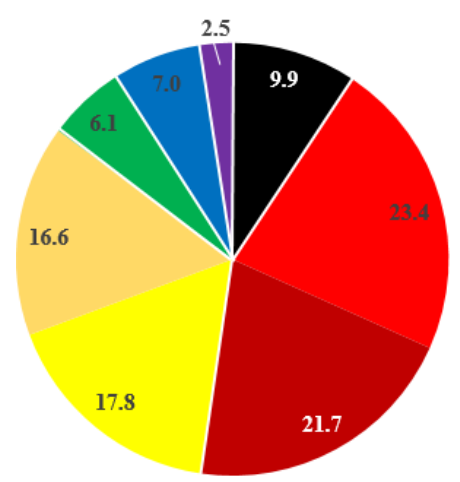

(d)

Figure 2. Percent of different ringed PAHs for each season: (a) Winter, (b) Spring, (c) Summer, and (d) Fall.

The five diagnostics ratios (DRs) used in this study to estimate the source characteristics of PAHs are shown in Table 6. Four of them-IcdP/IcdP+BghiP [34,35], Fl/Fl + Py [35-37], BaP/BghiP [38,39], $\mathrm{BaA} / \mathrm{BaA}+\mathrm{Chr}$ [37] - were used to separate coal and biomass combustion and vehicular emissions (Table 6). As seen in Table 6, separation of coal and biomass combustion is limited using DR of specific PAH compounds due to overlapping DR of biomass burning and coal combustion. So, in this study, the emission sources of PAHs can be only separated into solid fuel combustion, which includes both of coal and biomass combustion with vehicular exhaust emission. 
Table 6. Diagnostics Ratio (DR) for anlaysis.

\begin{tabular}{cccccc}
\hline & $\begin{array}{c}\text { IcdP/ } / \text { Bl } \\
\text { (IcdP + BghiP) }\end{array}$ & Fl/(Fl + Py) & BaP/BghiP & BaA/ & BaP/ \\
(BaA + Chr) & $\mathbf{( B a P + ~ B e P ) ~}$ \\
\hline Coal combustion & $0.56[35]$ & $>0.5[37,38]$ & $0.9-6.6[39,40]$ & $>0.35[38]$ & \\
Vehicular Emission & $0.18-0.40[35,36]$ & $0.4-0.5[36-38]$ & $0.3-0.44[40]$ & $0.2-0.35$ & \\
Wood Combustion & $0.62[35]$ & $>0.5[37]$ & & & $\sim 0.5[40]$ \\
Fresh Particle & & & & $<0.5[40]$ \\
Aging Particle & & & & \\
\hline
\end{tabular}

Figure 3a-e shows seasonal box plots of PAH DRs. There is a clear distinction between winter and summer season PAH emission sources, where winter PAH sources are a mixture of of solid fuel (coal + biomass) combustion and vehicular emissions, and summer is more affected with vehicular emissions.

Particle aging was evaluated with the remaining ratio $\mathrm{BaP} / \mathrm{BaP}+\mathrm{BeP}[40]$, shown in Figure 3e. The higher intensity of the photochemical reactions in summer shows well the aged characteristics of the sampled PM. However, particle aging can also be observed in other seasons, including winter, a season that provides the least factors for atmospheric reactions, implying the possibility for PAH transport from outside of Seoul (Figure 3).

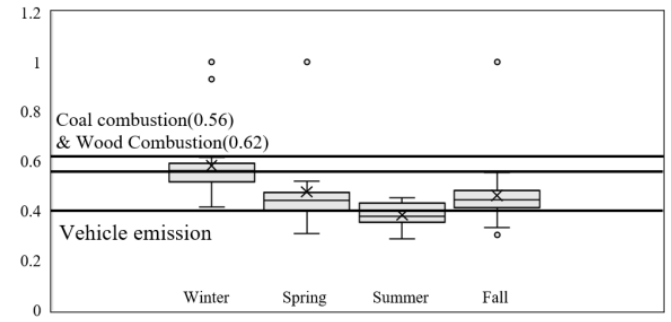

(a)

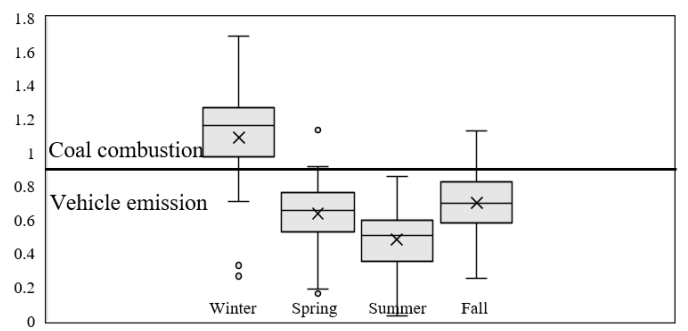

(c)

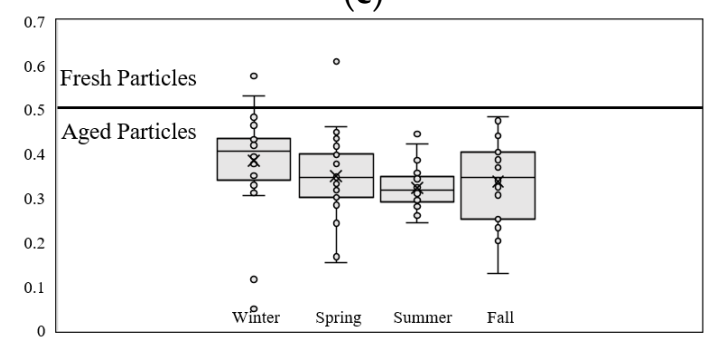

(e)

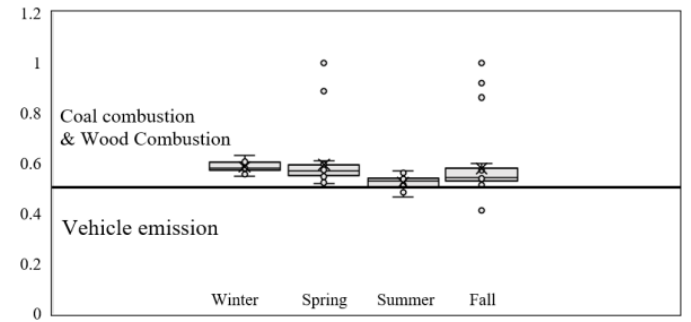

(b)

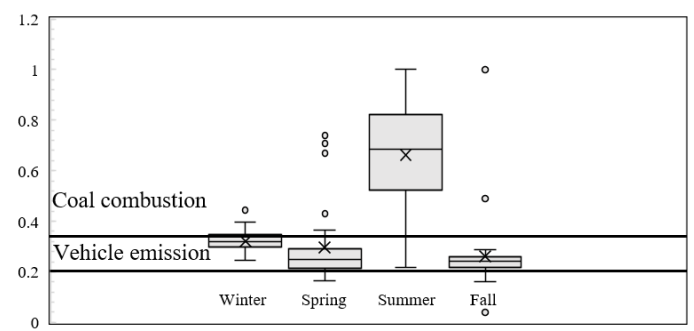

(d)

Figure 3. Diagnostics Ratio of PAHs. (d) $\mathrm{BaA} / \mathrm{BaA}+\mathrm{Chr}(\mathbf{e}) \mathrm{BaP} / \mathrm{BaP}+\mathrm{BeP}$.

(a) IcdP/IcdP+BghiP; (b) FL/Fl+Py; (c) BaP/BghiP;

\subsection{2. n-Alkane Seasonal Characteristics}

Shorter chained n-alkanes (C 25) are a known source of fossil fuel combustion. Plant wax emissions contribute to longer chained n-alkanes (C 25) with odd number carbons [28,41-45]. Figure 4a-d shows figures of averaged seasonal concentrations of $n$-alkanes. In order to compare the distribution of 
n-alkane concentrations by carbon number, the scale of the y axis for each figure was applied differently. The ratio of carbon chains shorter than C25 was higher in the winter compared to the other seasons, while the odd chained carbons longer than C25 gain importance from winter to summer (Figure 4).

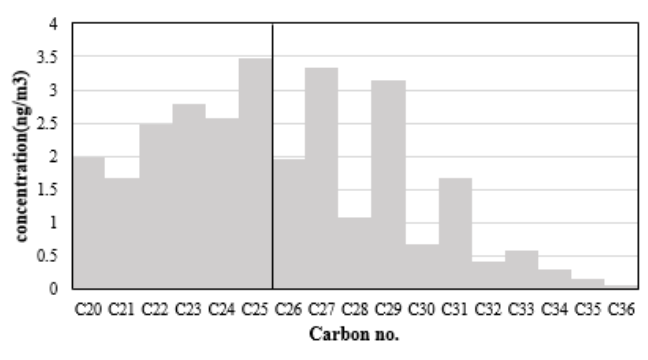

(a)

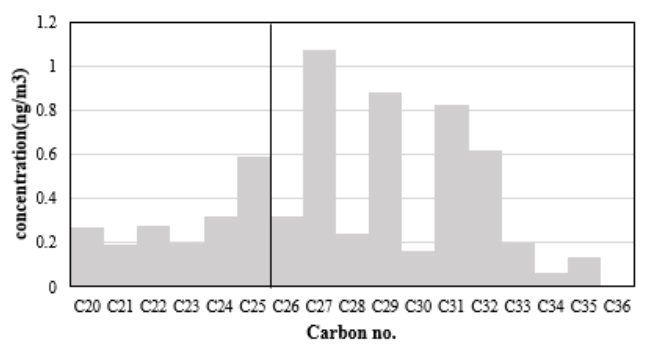

(c)

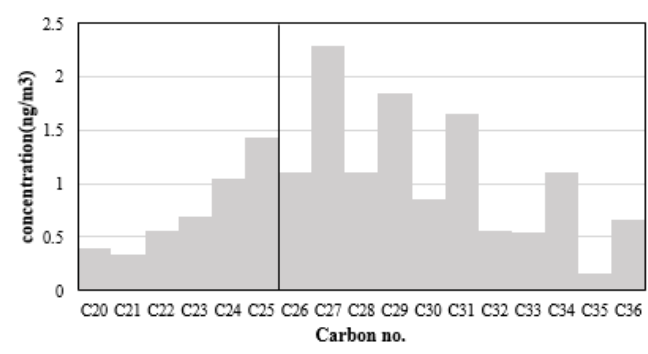

(b)

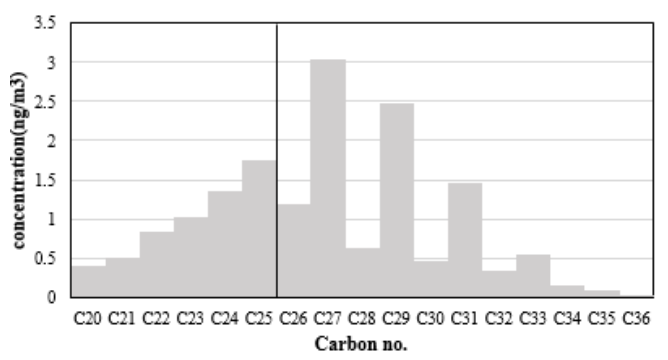

(d)

Figure 4. Seasonal averaged n-alkane concentrations. (a) Winter; (b) Spring; (c) Summer; (d) Fall. The scale of the $y$ axis for each figure is different.

Figure 5 shows the correlation between CPI value and WNA. The correlation value was calculated as $\mathrm{R}=0.69$, a moderate correlation $(0.5<\mathrm{R}<0.7)$, meaning CPI and WNA are a good index for source contribution evaluation [46-49]. In Table 7, the calculated seasonal average CPI values range from 1.43 to 1.97. From winter to fall, CPI is closest to 1 in the winter and spring and increases onwards. WNA increases up to the summer season, then drops in fall. In addition, C27, C29, and C31 n-alkanes peak in all seasons. All of the information suggests that the entire sampling period was affected by plant wax sources, which was more significant in the warmer seasons such as summer, and the anthropogenic combustion sources dominated n-alkane production, especially in the winter compared to the other sampling periods (Figure 5) (Table 7).

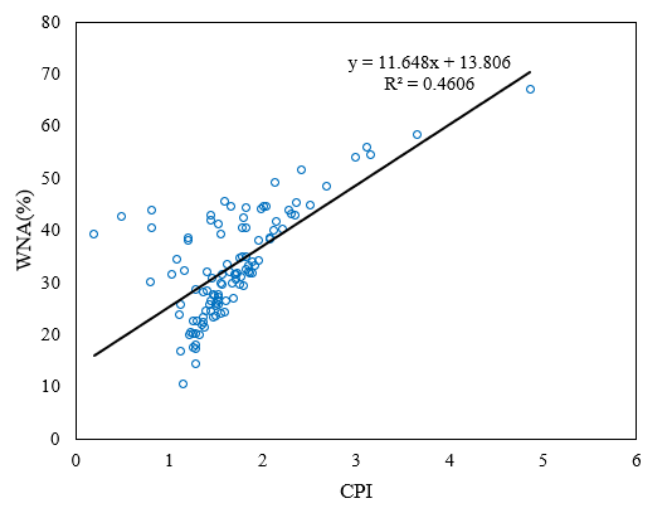

Figure 5. Carbon preference index (CPI) and wax n-alkanes percentage (WNA) correlation Plot. 
Table 7. Seasonal n-Alkane index.

\begin{tabular}{ccccc}
\hline Index & Winter & Spring & Summer & Fall \\
\hline Cmax & $25,27,29$ & $27,29,31$ & $27,29,31$ & $27,29,31$ \\
CPI & $1.43 \pm 0.3$ & $1.43 \pm 0.6$ & $1.80 \pm 0.6$ & $1.97 \pm 0.6$ \\
WNA (\%) & $23.8 \pm 6.2$ & $28.1 \pm 9.8$ & $42.5 \pm 6.5$ & $36.8 \pm 8.9$ \\
Fuel Combustion (\%) & 76.2 & 71.9 & 57.5 & 63.2 \\
\hline
\end{tabular}

\subsection{PCA Analysis}

PCA was performed to group measured species with common variances, i.e., principal components. Normally, the first principal component would represent the highest variance, followed by the second and third, and so on. Species showing higher values for each factor were considered to share an origin. For PCA, the concentration of $14 \mathrm{PAH}$ and $16 \mathrm{n}$-alkane compounds were applied as variables into the SPSS 18.0 statistical software [50] for 108 total $\mathrm{PM}_{2.5}$ samples. Varimax rotation was used to get as many positive loadings as possible to achieve a more meaningful and interpretable solution for air pollutants data suggested from previous studies [31,32]. N-alkanes were accounted into two groups: low ( $\left.\sum \mathrm{C} 20-\mathrm{C} 25\right)$ and high ( $\left.\sum \mathrm{C} 26-\mathrm{C} 36\right)$ molecular weight $(\mathrm{MW})$ to characterize fossil fuel combustion and biogenic emission, respectively. For 14 PAHs, each ring-group of PAHs were used as indicator to distinguish the combustion sources of solid fuel (coal + biomass) and liquid fuel (vehicular emission). Combustion of solid fuels such as coal and biomass mainly emit PAHs that have three and four benzene rings, and liquid fuel combustion such as vehicular emissions is a source for PAHs with five or more benzene ring [18-21]. Sensitivity analysis by number of variable was conducted in PCA and those results were found to be relatively consistent.

Five factors were extracted as the results of eigenvalue larger than 1. Generally eigenvalue larger than 1 is chosen for valuable components, however, the rapid change of slope were appeared at component 4 from scree plot shown in Figure 6. Thus, three components were valuable to identify sources of PAHs and n-Alkanes in PM2.5. Indeed, variance for Factors 4 and 5 were $7 \%$ and 6\%, respectively, which was insignificant compared to Factor 1 (25\%), Factor $2(21 \%)$, and Factor $3(16 \%)$.

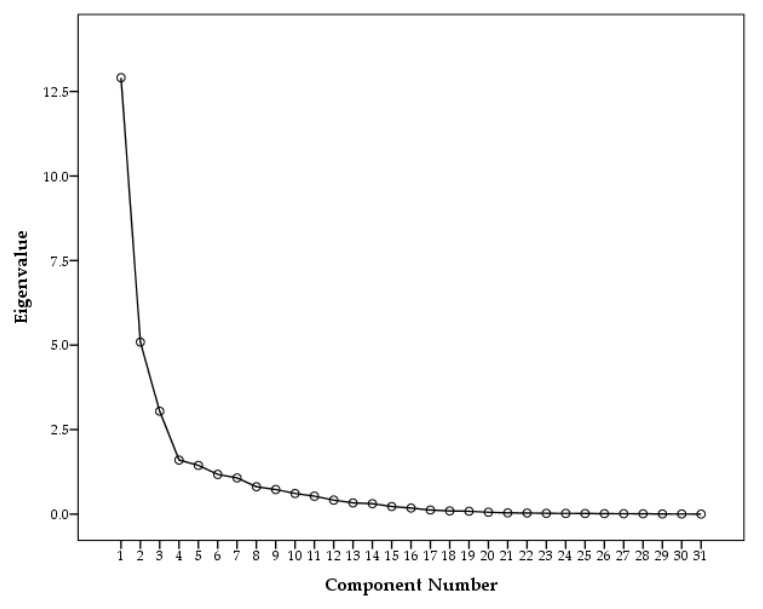

Figure 6. Scree plot of the Principle Component Analysis.

Table 8 shows the results of the PCA analysis for total $\mathrm{PM}_{2.5}$ samples. Three factors are identified and these account for $62.6 \%$ of the variability in the data. Factor 1 was explained as a mixture of vehicle emissions and solid fuel combustion, as the significance of both LMW-PAHs (Phe, Ant, Fl) [21] and HMW-PAHs, such as Ind and BghiP $[40,46]$ with n-alkanes shorter than C25, were grouped together. Contrary to Factor 1, only PAHs with 5 6 rings were highly loaded with shorter chained n-alkanes. Thus, Factor 2 was identified as a vehicular source. Vehicular emissions in factor 1 were separated with Factor 2, which might be related to the difference of the origin of the vehicular emissions for Factors 1 
and 2. Factor 3 only highlights n-alkanes over C27, which are markers of biogenic sources [28,41-45] (Table 8).

Table 8. Principle Component Analysis(PCA) factor loadings (only the values larger than 0.5 were marked as bold) for the entire sampling period.

\begin{tabular}{|c|c|c|c|}
\hline & \multicolumn{3}{|c|}{ Component } \\
\hline & 1 & 2 & 3 \\
\hline Phe & 0.960 & 0.031 & 0.007 \\
\hline Ant & 0.628 & -0.015 & 0.046 \\
\hline Flt & 0.933 & 0.183 & 0.027 \\
\hline Pyr & 0.923 & 0.198 & 0.044 \\
\hline $\mathrm{BaA}$ & 0.524 & 0.095 & 0.082 \\
\hline Chr & 0.408 & 0.216 & 0.052 \\
\hline $\mathrm{BbF}$ & 0.124 & 0.915 & 0.059 \\
\hline $\mathrm{BeP}$ & 0.113 & 0.910 & 0.058 \\
\hline $\mathrm{BaP}$ & 0.770 & 0.290 & 0.078 \\
\hline Perly & 0.718 & -0.016 & 0.081 \\
\hline IcdP & 0.607 & 0.535 & 0.122 \\
\hline DahA & 0.180 & -0.009 & -0.013 \\
\hline BghiP & 0.530 & 0.345 & 0.122 \\
\hline Cor & 0.205 & 0.242 & 0.138 \\
\hline $\mathrm{C} 20$ & 0.878 & 0.237 & 0.045 \\
\hline $\mathrm{C} 21$ & 0.827 & 0.379 & 0.058 \\
\hline $\mathrm{C} 22$ & 0.660 & 0.571 & 0.102 \\
\hline $\mathrm{C} 23$ & 0.497 & 0.738 & 0.145 \\
\hline $\mathrm{C} 24$ & 0.293 & 0.833 & 0.176 \\
\hline $\mathrm{C} 25$ & 0.135 & 0.914 & 0.137 \\
\hline $\mathrm{C} 26$ & 0.193 & 0.851 & 0.289 \\
\hline $\mathrm{C} 27$ & 0.013 & 0.700 & 0.269 \\
\hline $\mathrm{C} 28$ & 0.037 & 0.317 & 0.896 \\
\hline $\mathrm{C} 29$ & 0.244 & 0.450 & 0.800 \\
\hline C30 & -0.013 & 0.286 & 0.904 \\
\hline C31 & 0.107 & 0.144 & 0.934 \\
\hline $\mathrm{C} 32$ & -0.080 & -0.132 & 0.667 \\
\hline $\mathrm{C} 33$ & 0.157 & 0.165 & 0.826 \\
\hline $\mathrm{C} 34$ & -0.039 & -0.099 & 0.652 \\
\hline C35 & 0.074 & 0.144 & 0.226 \\
\hline $\mathrm{C} 36$ & -0.035 & 0.001 & -0.047 \\
\hline Eigenvalue & 12.907 & 5.5089 & 3.042 \\
\hline Variance (\%) & 24.9 & 21.4 & 16.3 \\
\hline Source & Coal and Biomass/Vehicle mix & Vehicle & Biogenic \\
\hline
\end{tabular}

Figure 7 shows both the loading and score plot of PCA analysis for three factors. Winter and other seasons'(spring, summer, fall) samples were well separated (Figure 7a,b) which indicates different emission sources. The lower right part of the score plot is dominated by winter samples, which is characterized by LMW-PAHs, HMW-PAHs and lower chained n-alkanes in the loading plot (Figure 7b). Therefore a mixture of solid fuel combustion and vehicle emission is a major influence on winter atmosphere. Fall samples mostly overlapped with spring and summer samples in the lower left corner of the score plot, which implies the samples of these seasons has similar emission source. The overlapped area of the three seasons all included HMW-PAHs (DahA, Cor) and longer chained $(C>25)$ in the loading plot. Thus we can expect that spring, summer and fall were mainly influenced by biogenic emissions and vehicular emission 

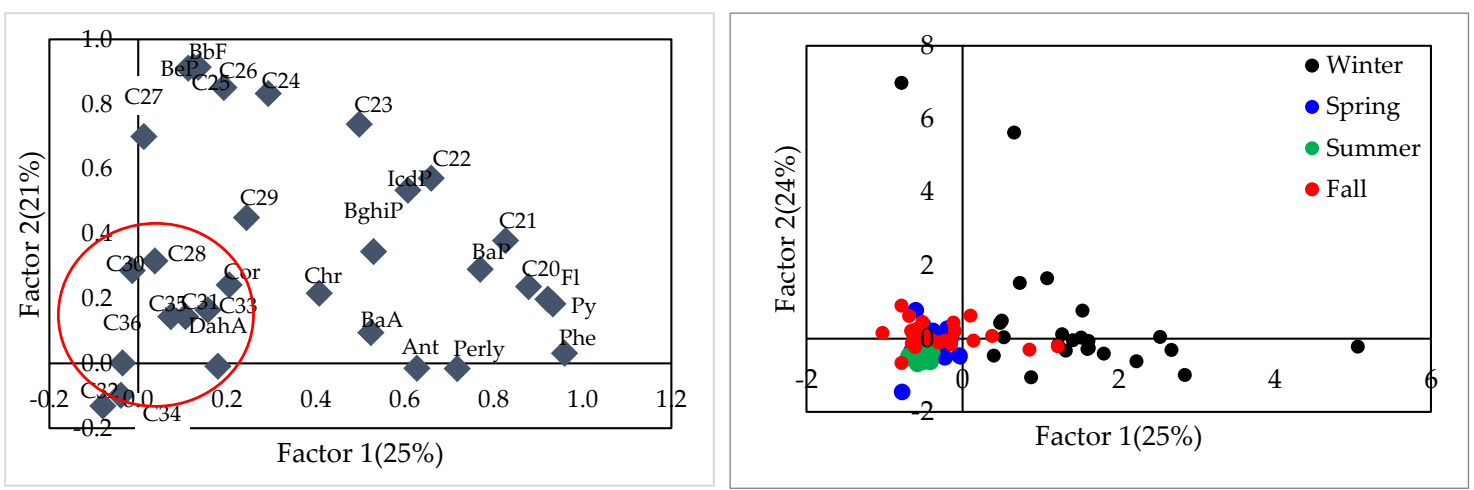

(a)
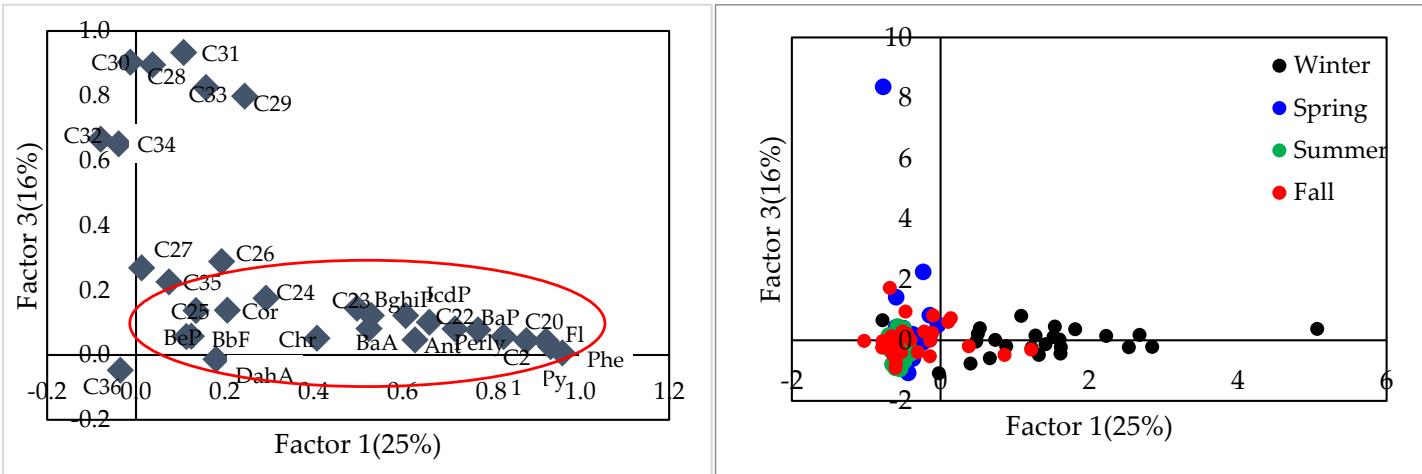

(b)
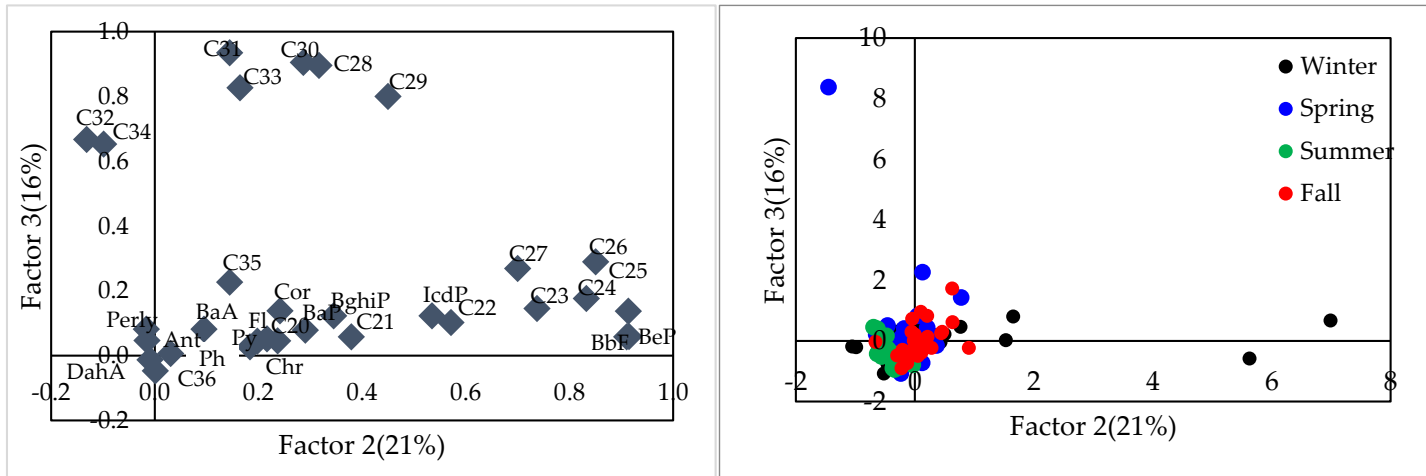

(c)

Figure 7. Loading plots and Score plots of (a) Factor 1 and Factor 2; (b) Factor 1 and Factor 3; (c) Factor 2 and Factor 3.

\subsection{Back Trajectory Result}

Figure 8a-d shows the seasonal cluster of three day back trajectory performed with HYSLPLIT, and averaged wind speed and direction calculated with WINDROSE. Since wind information at the $\mathrm{PM}_{2.5}$ sampling site was not measured, data from a meteorological station in Seoul (Station ID: 108, $37^{\circ} 34^{\prime} \mathrm{N}, 126^{\circ} 57^{\prime}$ E) was utilized.

In the HYSLPLIT analysis, five clusters were extracted in the winter season. Along with local wind direction and speed, wind parcels from the Northwest of Korea were dominant. Meanwhile, cluster $1(24 \%)$ and cluster $4(27 \%)$, which was from the East of Korea in summer, took up more than half the fraction of the total cluster. These two clusters might be highly affected by local emission sources. Spring and fall show a pattern mixture of summer and winter. In Spring, $67 \%$ of the back trajectory was identified as local emission sources due to air parcels from the East of Korea, and the 
next abundant cluster, which was from Russia, took up $22 \%$ of spring back trajectory. Wind from the west was dominant for local wind direction, but the Northeast frequency increased compared to the previous season. In fall, 20\% (Cluster 2) of clusters passed to the east side of the Korean peninsula, local transport, and the rest from the west.
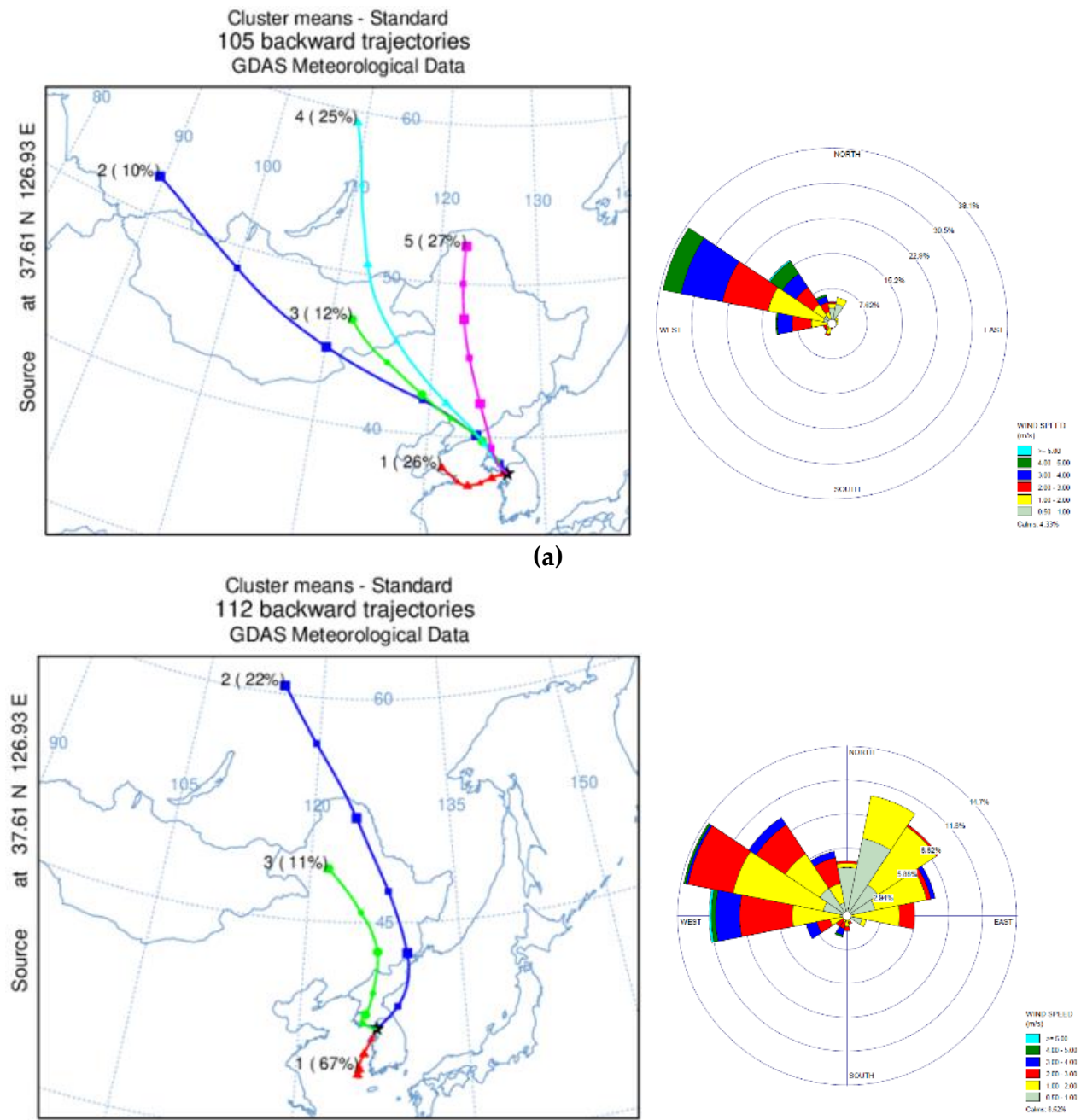

(b)

Figure 8. Cont. 


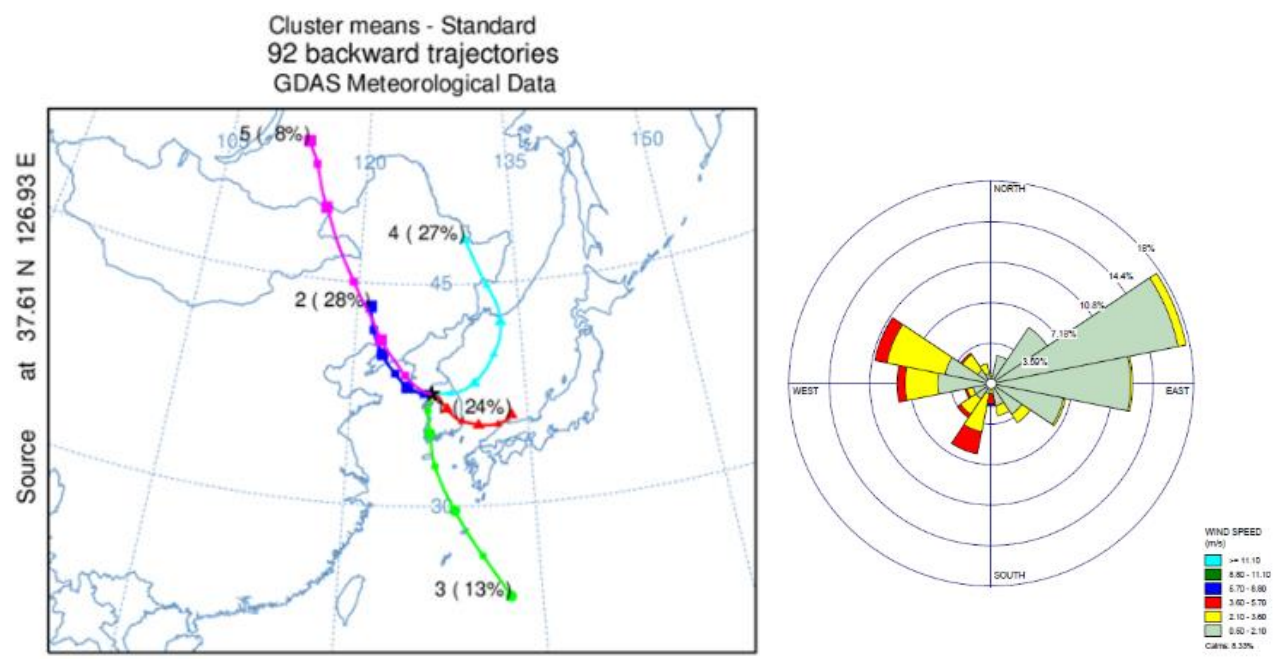

(c)

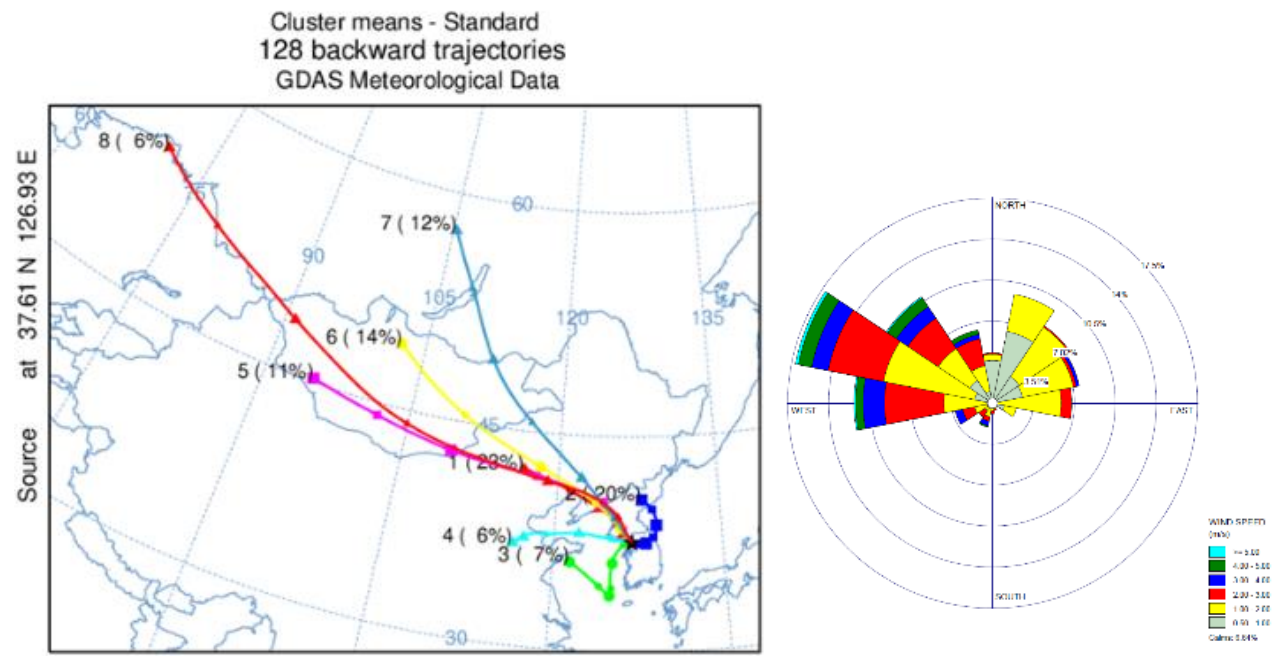

(d)

Figure 8. Seasonal back trajectory cluster analysis performed with HYSPLIT and averaged wind direction and speed analysis performed with WINDROSE. (a) Winter; (b) Spring; (c) Summer; (d) Fall.

Seasonal differences in PAH emission sources were observed in the diagnostic ratios of the previous section, with winter having relatively dominant coal and biomass combustion sources. The back trajectory and local wind direction results of Factor 1 of the PCA analysis, identified as a mix of coal and biomass combustion and vehicular emissions, support PAHs derived from these sources which likely originated from outside of Seoul, especially the northwest region of China. The summer diagnostics ratio and Factor 2 of the PCA analysis from the previous section indicates a dominance of vehicular emissions, and the back trajectory and local wind direction show the locality of PAH source of summer.

\subsection{Toxic Equivalency Quotient (TEQ) and Mutagenic Equivalency (MEQ) of PAHs in PM2.5}

Since some of the PAH compounds are carcinogen, it is important to estimate the health effect from these compounds to the people in Seoul, Korea due to the high population concentrations in this region. There are two types of methods to estimate health effects due to PAH compounds-one is the toxicity equivalency factor (TEF) [51] and the other is the mutagenic equivalency factor (MEF) [52]. The reference compound is $\mathrm{BaP}$, which is known to be the most harmful PAH compound. The TEF reflects for relative potency of individual $\mathrm{PAH}$ compounds to $\mathrm{BaP}$, while the MEF assesses mutagenicity of individual $\mathrm{PAH}$ compounds relative to $\mathrm{BaP}$, representing the potential risks for non-cancerous 
adverse health effects. BaP-TEQ and BaP-MEQ were calculated by multiplying the concentrations of each compound with its TEF and MEF values, respectively, as shown below.

$($ BaP-TEQ $)=\{$ Phen $\} \times 0.001+\{$ Anthr $\} \times 0.01+\{$ Flt $\} \times 0.001+\{$ Pyr $\} \times 0.001+\{\mathrm{B}(\mathrm{a}) \mathrm{A}\} \times 0.1+\{$ Chry $\}$ $\times 0.01+\{\mathrm{B}(\mathrm{b}) \mathrm{F}\} \times 0.1+\{\mathrm{B}(\mathrm{k}) \mathrm{F}\} \times 0.1+\{\mathrm{B}(\mathrm{a}) \mathrm{P}\} \times 1+\{\mathrm{D}(\mathrm{ah}) \mathrm{A}\} \times 5+\{\mathrm{Ind}\} \times 0.1+\{\mathrm{B}(\mathrm{ghi}) \mathrm{P}\} \times 0.01$

$(\mathrm{BaP}-\mathrm{MEQ})=\{\mathrm{B}(\mathrm{a}) \mathrm{A}\} \times 0.082+\{\mathrm{Chry}\} \times 0.017+\{\mathrm{B}(\mathrm{b}) \mathrm{F}\} \times 0.25+\{\mathrm{B}(\mathrm{k}) \mathrm{F}\} \times 0.11+\{\mathrm{B}(\mathrm{e}) \mathrm{P}\} \times 0.002+$ $\{\mathrm{B}(\mathrm{a}) \mathrm{P}\} \times 1+\{\mathrm{I}(1,2,3-\mathrm{cd}) \mathrm{P}\} \times 0.31+\{\mathrm{D}(\mathrm{ah}) \mathrm{A}\} \times 0.29+\{\mathrm{B}(\mathrm{ghi}) \mathrm{P}\} \times 0.19$

Table 9 shows a comparison of TEQ and MEQ of PAHs in 2002 and 2018 measured in Seoul, Korea. The 2018 observation showed one order lower values of both toxicity and mutagenicity than 2002. The highest average BaP-TEQ was observed in winter in both $2002\left(7.15 \pm 4.8 \mathrm{ng} \mathrm{m}^{-3}\right)$ and 2018 $\left(1.86 \pm 2.0 \mathrm{ng} \mathrm{m}^{-3}\right), 2002$ showing about 3 times the toxicity compared to 2018 . Summer recorded the lowest BaP-TEQ in both $2002\left(1.78 \pm 1.0 \mathrm{ng} \mathrm{m}^{-3}\right)$ and $2018\left(0.08 \pm 0.09 \mathrm{ng} \mathrm{m}^{-3}\right), 2018$ being 22 times lower toxicity than 2002.

Table 9. Seasonal and Annual average toxicity evaluation of PAHs in 2002 and 2019 (unit: $\mathrm{ng} \mathrm{m}^{-3}$ ).

\begin{tabular}{cccccc}
\hline & \multicolumn{2}{c}{ 2018 } & & & \\
& Winter & Spring & Summer & Fall & Annual \\
\hline BaP-TEQ & $1.86 \pm 2.0$ & $0.17 \pm 0.14$ & $0.08 \pm 0.09$ & $0.28 \pm 0.17$ & $0.59 \pm 1.20$ \\
BaP-MEQ & $2.02 \pm 1.75$ & $0.24 \pm 0.19$ & $0.14 \pm 0.13$ & $0.43 \pm 0.27$ & $0.70 \pm 1.16$ \\
China Standard $^{1}$ & $5 / 25^{3}$ & $0 / 28$ & $0 / 23$ & $0 / 32$ & - \\
WHO Standard $^{2}$ & $17 / 25$ & $0 / 28$ & $0 / 23$ & $0 / 32$ & - \\
\hline \multicolumn{7}{c}{$\mathbf{2 0 0 2}$} \\
BaP-TEQ & Winter & Spring & Summer & Fall & Annual \\
BaP-MEQ & $7.15 \pm 4.8$ & $4.76 \pm 3.0$ & $1.78 \pm 1.0$ & $4.57 \pm 5.3$ & $4.69 \pm 4.5$ \\
China Standard $^{1}$ & $6.73 \pm 4.3$ & $3.96 \pm 2.5$ & $1.37 \pm 0.8$ & $3.28 \pm 4.2$ & $3.97 \pm 4.0$ \\
WHO Standard $^{2}$ & $20 / 21$ & $7 / 10$ & $2 / 17$ & $10 / 20$ & - \\
\hline
\end{tabular}

${ }^{1}$ Chinese NAAQS daily BaP-TEQ standard $\left(2.5 \mathrm{ng} \mathrm{m}^{-3}\right) .{ }^{2}$ WHO BaP-TEQ standard $\left(1 \mathrm{ng} \mathrm{m}^{-3}\right) .{ }^{3}$ Days that exceeded the standard/Number of Sampling days.

Since South Korea has not specified a PAH ambient air standard, this study applied the Chinese National Ambient Air Quality Standard (GB 3095-2012) [4] annual standard $1 \mathrm{ng} \mathrm{m}^{-3}$. The number of sampling days in 2002 that exceeded this standard was 20 times in winter, 7 in spring, 2 in summer, but none in fall, while in 2018, only 5 days did not meet in winter and for the whole sampling period. The application of WHO's stricter standard $1 \mathrm{ng} \mathrm{m}^{-3}$ [53] added the days that exceeded the standard, as shown in Table 9. However, in 2018, all seasons except winter met the WHO standard.

This result revealed that recent BaP-TEQ in $\mathrm{PM}_{2.5}$ in Seoul, Korea satisfied both Chinese NAAQS and WHO's strict standard except winter. However, still, the toxicity of $\mathrm{PM}_{2.5}$ can be increased due to high concentrations of PAHs in PM2.5 during winter. In order to minimize the toxicity (i.e., cancer risk) by PAHs in PM2.5, continuous monitoring of PAHs in $\mathrm{PM}_{2.5}$ with establishment of air quality standard is required (Table 9).

\section{Summary and Conclusions}

In this study, we found that recent PAH concentrations in $\mathrm{PM}_{2.5}$ in Seoul, Korea were affected by the combination of solid fuel (coal + biomass) combustion and vehicular emissions in the winter season by the diagnostics ratio and PCA result. The n-alkane index supports these results. The back trajectory traces the sources back to the far northwest of the Korean peninsula. While, in summer, vehicle emissions were dominant and cluster analysis indicates that this is mainly due to the local emission effect.

Comparison of 2002 PAH data, recent PAH concentrations in $\mathrm{PM}_{2.5}$ (measured in 2018) showed a drastic decrease in both toxicity and mutagenicity. In 2018, BaP-TEQ exceeded the Chinese NAAQS and WHO standard only in winter, a season most affected by the mixture of coal and biomass combustion 
and vehicular emissions and air parcels traveling from the Northwest region of Korea. Therefore, the control of PM2.5 toxicity in Seoul needs to focus on the regulation of PAH emission sources in the winter season.

Author Contributions: Data curation, M.K.; Investigation, M.K. and K.K.; Methodology, K.K. and N.C.; Validation and Visualization, M.K..; Writing-original draft, M.K. and J.Y.L.; Writing-review \& editing, Y.P.K. and J.Y.L. All authors have read and agreed to the published version of the manuscript.

Acknowledgments: This research was supported by the National Strategic Project-Fine Particle of the National Research Foundation of Korea (NRF) funded by the Ministry of Science and ICT (MSIT), the Ministry of Environment (ME), and the Ministry of Health and Welfare (MOHW) (2017M3D8A1092015). Also, this work was supported by the Ewha Womans University Research Grant of 2018.

Conflicts of Interest: The authors declare no conflicts of interest.

\section{References}

1. Tobiszewski, M.; Namie śnik, J. PAH diagnostic ratios for the identification of pollution emission sources. Environ. Pollut. 2012, 162, 110-119. [CrossRef] [PubMed]

2. Schauer, J.J.; Rogge, W.F.; Hildemann, L.M.; Mazurek, M.A.; Cass, G.R. Source apportionment of airborne particulate matter using organic compounds as tracers. Atmos. Environ. 1996, 30, 3837-3855. [CrossRef]

3. Air Quality Standards. European Commission. Available online: https://ec.europa.eu/environment/air/ quality/standards.htm (accessed on 16 December 2019).

4. Ministry of Environmental Protection of the People's Republic of China. Ambient Air Quality Standard; GB 3095-2012; Ministry of Environmental Protection of the People's Republic of China: Beijing, China, 2012.

5. Bi, X.; Sheng, G.; Peng, P.A.; Chen, Y.; Zhang, Z.; Fu, J. Distribution of particulate-and vapor-phase n-alkanes and polycyclic aromatic hydrocarbons in urban atmosphere of Guanzhou, China. Atmos. Environ. 2003, 37, 289-298. [CrossRef]

6. Fraser, M.P.; Cass, G.R.; Simoneit, B.R. Particulate organic compounds emitted from motor vehicle exhaust and in the urban atmosphere. Atmos. Environ. 1999, 33, 2715-2724. [CrossRef]

7. Limbeck, A.; Puxbaum, H. Organic acids in continental background aerosols. Atmos. Environ. 1999, 33, 1847-1852. [CrossRef]

8. Simoneit, B.R.T. Organic matter in eolian dusts over the Atlantic Ocean. Mar. Chem. 1977, 5, $443-464$. [CrossRef]

9. Yassa, N.; Meklati, B.Y.; Cecinato, A.; Marino, F. Particulate n-alkanes, n-alkanoic acids and polycyclic aromatic hydrocarbons in the atmosphere of Algiers City Area. Atmos. Environ. 2001, 35, 1843-1851. [CrossRef]

10. Hong, S.B.; Kang, C.H.; Kim, W.H.; Kim, Y.P.; Lee, S.M.; Kim, Y.S.; Song, C.H.; Chung, C.H.; Hong, J.H. PAHs concentrations of $\mathrm{PM}_{10}$ in Seoul Metropolitan Area. J. KOSAE 2009, 25, 347-359. [CrossRef]

11. Kim, H.G.; Chung, K.M.; Kim, T.S. Characteristics of Seasonal Distributions of Fine Particles $\left(\mathrm{PM}_{2.5}\right)$ and Particle-Associated Polycyclic Aromatic Hydrocarbons in Urban, Metropolitan and Industrial Complex Sites. J. Environ. Toxicol. 2006, 21, 45-56.

12. Jung, K.S.; Kwon, H.O.; Lee, Y.S.; Jung, S.M.; Oh, J.E.; Choi, S.D. Preliminary Study on Characteristics of Atmospheric Polycyclic Aromatic Hydrocarbons in a Mega-city. J. KSEA 2013, 16, 239-249.

13. Choi, J.K.; Heo, J.B.; Ban, S.J.; Yi, S.M.; Zoh, K.D. Chemical Characteristics of PM2.5 aerosol in Incheon, Korea. Atmos. Environ. 2012, 60, 583-592. [CrossRef]

14. Baek, K.M.; Seo, Y.K.; Chung, D.H.; Baek, S.O. Atmospheric Occurrence and Concentrations of PAHs and Heavy Metals in Pohang. J. KOSAE 2019, 35, 533-554. [CrossRef]

15. Lee, J.Y.; Kim, Y.P.; Kaneyasu, N.; Kumata, H.; Kang, C.H. Particulate PAHs levels at Mt. Halla site in Jeju Island, Korea: Regional background levels in northeast Asia. Atmos. Res. 2008, 90, 91-98. [CrossRef]

16. Lee, J.Y.; Kim, Y.P. Source apportionment of the particulate PAHs at Seoul, Korea: Impact of long range transport to a megacity. Atmos. Chem. Phys. 2007, 7, 3587-3596. [CrossRef]

17. Han, S.H.; Lee, J.Y.; Heo, J.B.; Kim, Y.P. Temporal Trend of the Major Contributors for the Particulate Polycyclic Aromatic Hydrocarbons (PAHs) in Seoul. AAQR 2019, 19, 318-330. [CrossRef] 
18. Byambaa, B.; Yang, Lu.; Matsuki, A.; Nagato, E.G.; Gankhuyang, K.; Chuluunpurev, B.; Banzragch, L.; Chonokhuu, S.; Tang, N.; Hayakawa, K. Sources and Characteristics of Polycyclic Hydrocarbons in Ambient Total Suspended Particles in Ulanbaatar City, Mongolia. Int. J. Environ. Res. Public Health 2019, 16, 442. [CrossRef]

19. Fan, X.; Chen, Z.; Liang, L.; Qui, G. Atmospheric $\mathrm{PM}_{2.5}$-Bound Polycyclic Aromatic Hydrocarbons (PAHs) in Guiyang City, Southwest China: Concentration, Seasonal Variation, Sources and Health Risk Assessment. AECT 2018, 76, 102-113. [CrossRef]

20. Liu, J.; Man, R.; Ma, S.; Li, J.; Wu, Q.; Peng, J. Atmospheric levels and health risk of polycyclic aromatic hydrocarbons (PAHs) bound to $\mathrm{PM}_{2.5}$ in Guangzhou, China. Mar. Pollut. Bull. 2015, 100, 134-143. [CrossRef]

21. Miura, K.; Shimada, K.; Sugiyama, T.; Sato, K.; Takami, A.; Chan, C.K.; Kim, I.S.; Kim, Y.P.; Lin, N.H.; Hatakeyama, S. Seasonal and annual changes in PAH concentrations in a remote site in the Pacific Ocean. Sci. Rep. 2019, 9, 1-10. [CrossRef]

22. USEPA. Supplementary Guidance for Conducting Health Risk Assessment of Chemical Mixtures; Risk Assessment Forum Technical Panel EPA/630/R-00/002; U.S. Environmental Protection Agency: Washington, DC, USA, 2000.

23. Mostert, M.M.R.; Ayoko, G.A.; Kokot, S. Application of chemometrics to analysis of soil pollutants. Trends Anal. Chem. 2010, 29, 430-435.

24. Hayakawa, K.; Murahashi, T.; Akutusu, K.; Kanda, T.; Tang, N.; Kakimoto, H.; Toriba, A.; Kizu, R. Comparison of polycyclic aromatic hydrocarbons in nitropolycyclic aromatic hydrocarbons in airborne and auromobile exhaust particulates. Polycycl. Aromat. Compd. 2000, 20, 179-190. [CrossRef]

25. Masclet, P.; Mouvier, G.; Nikolaou, K. Relative decay index and sources of polycyclic aromatic hydrocarbons. Atmos. Envrion. 1986, 20, 439-446. [CrossRef]

26. Li, Z.; Chen, L.; Liu, S.; Ma, H.; Wang, L.; An, C.; Zhang, R. Characterization of PAHs and PCBs in Fly Ahses of Eighteen Coal-Fired Power Plants. AAQR 2016, 16, 3175-3186.

27. Mazurek, M.A.; Cass, G.R.; Simoneit, B.R. Interpretation of high-resolution gas chromatography and high-resolution gas chromatography/mass spectrometry data acquired from atmospheric organic aerosol samples. Aerosol Sci. Technol. 1989, 10, 408-420. [CrossRef]

28. Simoneit, B.R.T. Organic matter of the troposphere-V: Application of molecular marker anlaysis to biogenic emissions into the troposphere for source reconciliations. J. Atmos. Chem. 1989, 8, 251-275. [CrossRef]

29. Eichmann, R.; Neuling, P.; Ketseridis, G.; Hahn, J.; Jaenicke, R.; Junge, C. n-Alkane studies in the troposphere-I. Gas and particulate concentrations in North Atlantic air. Atmos. Environ. 1979, 13, 587-599. [CrossRef]

30. Simoneit, B.R.; Sheng, G.; Chen, X.; Fu, J.; Zhang, J.; Xu, U. Molecular marker study of extractable organic matter in aerosols from urban areas of China. Atmos. Environ. 1991, 25, 2111-2129. [CrossRef]

31. Manoli, e.; Voutsa, D.; Samara, C. Chemical characterization and source identification/apportionment of fine and coarse air particles in Thessaloniki, Greece. Atmos. Environ. 2002, 36, 949-961. [CrossRef]

32. Tauler, R.; Viana, M.; Querol, X.; Alastuey, A.; Flight, R.M.; Wentzell, P.D.; Hopke, P.K. Comparison of the results obtained by four receptor modelling methods in aerosol source apportionment studies. Atmos. Environ. 2009, 43, 3989-3997. [CrossRef]

33. Feng, B.; Li, L.; Xu, H.; Wang, T.; Wu, R.; Chen, J.; Zhang, Y.; Liu, S.; Ho, S.S.H.; Cao, J.; et al. PM 2.5 -bound polycyclic aromatic hydrocarbons (PAHs) in Beijing: Seasonal variations, sources, and risk assessment. Environ. Sci. 2018, 77, 11-19. [CrossRef]

34. Pio, C.A.; Alves, C.A.; Duarte, A.C. Identification, abundance and origin of atmospheric organic particulate matter in a Portuguese rural area. Atmos. Environ. 2001, 35, 1365-1375. [CrossRef]

35. Kavouras, I.; Lawrence, J.; Koutrakis, P.; Stephanou, E.; Oyola, P. Measurements of particulate aliphatic and polynuclear aromatic hydrocarbons in Santiago de Chile: Source reconciliation and evaluation of sampling artifacts. Atmos. Environ. 1999, 33, 4977-4986. [CrossRef]

36. Zencak, Z.; Klanova, J.; Holoubek, I.; Gustafsson, O. Source Apportionment of Atmospheric PAHs in the Western Balkans by Natural Abundance Radiocarbon Analysis. Environ. Sci. Technol. 2007, 41, 3850-3855. [CrossRef]

37. Yunker, M.B.; Macdonald, R.W.; Vingarzan, R.; Mitchell, R.D.; Goyette, D.; Sylvestre, S. PAHs in the Fraser River basin: A critical appraisal of PAH ratios as indicators of PAH source and composition. Org. Geochem. 2002, 33, 489-515. [CrossRef] 
38. Simcik, M.F.; Eisenreich, S.J.; Lioy, P.J. Source apportionment and source/sink relationships of PAHs in the coastal atmosphere of Chicago and Lake Michigan. Atmos. Environ. 1999, 33, 5071-5079. [CrossRef]

39. Wu, S.P.; Tao, S.; Zhang, Z.H.; Lian, T.; Zuo, Q. Characterization of TSP-bound n-alkanes and polycyclic aromatic hydrocarbons at rural and urban sites of Tianjin, China. Environ. Pollut. 2007, 147, 203-210. [CrossRef]

40. Olivera, C.; Martins, N.; Tavares, J.; Pio, C.; Cerqueria, M.; Matos, M.; Silva, H.; Olivera, C.; Camöes, F. Size distribution of polycyclic aromatic hydrocarbons in a roadway tunnel in Lisbon, Portugal. Chemosphere 2011, 83, 1588-1596. [CrossRef]

41. Sicre, M.A.; Peltzer, E.T. Lipid geochemistry of remote aerosols from them southwestern Pacific Ocean sector. Atmos. Environ. 2004, 38, 1615-1624. [CrossRef]

42. Zheng, M.; Wan, T.S.M.; Fang, M.; Wang, F. Characterization of the non-volatile organic compounds in the aerosols of Hong Kong-identification, abundance and origin. Atmos. Environ. 1997, 31, 227-237. [CrossRef]

43. Simoneit, B.R.; Kobayashi, M.; Mochida, M.; Kawamura, K.; Huebert, B.J. Aerosol particles collected on aircraft flights over the north western Pacific region during the ACE-Asia campaign: Composition and major sources of the organic compounds. J. Geophys. Res. 2004, 10. [CrossRef]

44. Rogge, W.F.; Hildemann, L.M.; Mazurek, M.A.; Cass, G.R.; Simoneit, B.R. Sources of fine organic aerosol. 4. Particulate abrasion products from leaf surfaces of urban plants. Environ. Sci. Technol. 1993, 27, 2700-2711. [CrossRef]

45. Rogge, W.F.; Hildemann, L.M.; Mazurek, M.A.; Cass, G.R.; Simoneit, B.R. Sources of fine organic aerosol.8. Boilers burning No.2 distillate fuel oil. Environ. Sci. Technol. 1997, 31, 2731-2737. [CrossRef]

46. Górka, M.; Rybicki, M.; Simoneit, B.R. Marynowski, L. Determination of multiple organic matter sources in aerosol $\mathrm{PM}_{10}$ from Wrocław, Poland using molecular and stable carbon isotope compositions. Atmos. Environ. 2014, 89, 739-748. [CrossRef]

47. He, J.; Zielinska, B.; Balasubramanian, R. Composition of semi-volatile organic compounds in the urban atmosphere of Singapore: Influence of biomass burning. Atmos. Chem. Phys. 2010, 10, 11401-11413. [CrossRef]

48. Wu, S.P.; Tao, S.; Zhang, A.J.; Lan, T.; Zuo, Q. Distribution of particle-phase hydrocarbons, PAHs and OCPs in Tianjin, China. Atmos. Environ. 2005, 39, 7420-7432. [CrossRef]

49. Gogou, A.; Stratigakis, N.; Kanakidou, M.; Stephanou, E.G. Organic aerosols in Eastern Mediterranean: Components source reconciliation by using molecular markers and atmospheric back trajectories. Org. Chem. 1996, 25, 2715-2724. [CrossRef]

50. Ijsmi, E. Tutorial: Factor analysis revisited-An overview with the help of SPSS, SAS and R packages. Int. J. Stat. Med. Inform. 2017, 3, 1-14.

51. Nisbet, I.C.T.; LaGoy, P.K. Toxic equivalency factors (TEFs) for polycyclic aromatic hydrocarbons (PAHs). Regul. Toxicol. Pharmacol. 1992, 16, 290-300. [CrossRef]

52. Durant, J.L.; Busby, W.F., Jr.; Lafleur, A.L.; Penman, B.W.; Crespi, C.L. Human cell mutagenicity of oxygenated, nitrated and unsubstituted polycyclic aromatic hydrocarbons associated with urban aerosols. Mutat. Res. Genet. Toxicol. 1996, 371, 123-157. [CrossRef]

53. World Health Organization. Polycyclic Aromatic Hydrocarbons (PAH). Air Quality Guidelines for Europe; World Health Organization Regional Office Europe: Copenhagen, Denmark, 1987; pp. 105-117.

(C) 2020 by the authors. Licensee MDPI, Basel, Switzerland. This article is an open access article distributed under the terms and conditions of the Creative Commons Attribution (CC BY) license (http://creativecommons.org/licenses/by/4.0/). 